overwhelming - particularly if prophylaxis with drugs such as propranolol is shown to be beneficial. Those who have not inherited the Marfan's gene will be spared unnecessary anxiety and investigation, whereas gene carriers could be entered into carefully planned surveillance programmes offering at the very least regular cardiac and ophthalmological assessment.

For isolated cases, accounting for perhaps one quarter to one third of all patients with Marfan's syndrome, and patients from families too small for linkage studies, preclinical and prenatal diagnosis will have to await elucidation of their specific gene defect. If the identification of point mutations and subtle rearrangements in the fibrillin gene proves to be as difficult as pinpointing the individual collagen mutations in osteogenesis imperfecta then specific molecular diagnosis is likely to be a long way off. This is particularly unfortunate given the existing problems in diagnosing apparently mild cases of Marfan's syndrome and allied conditions such as contractural arachnodactyly, which may be due to mutations in a fibrillin gene on chromosome $5^{5}$; the familial mitral valve prolapse syndrome; and other less certain entities such as the Marfanoid hypermobility syndrome.

Ultimately the discovery of the underlying basic genetic and protein defect must raise hope for the development of more effective therapeutic strategies. This alone would seem to justify the excitement generated by recent events. If attempts to identify a mutation in blood stains, bone, and hair from Abraham Lincoln are successful ${ }^{11}$ then the medical historians can justly take pride in their diagnostic acumen. Meanwhile patients with Marfan's syndrome can console themselves with the notion that they are in distinguished company.

Consultant Clinical Geneticist, IAN YOUNG:

City Hospital,

Nottingham NG1 6HA

Pyeritz RE. Marfan syndrome. In: Emery AEH, Rimoin DL, eds. Principles and practice of medicat genetics. 2nd ed. Edinburgh: Churchill Livingstone, 1990.

Beighton P, de Paepe A, Danks D, Finidori G, Gedde-Dahl T, Goodman R, et al. Internationa nosology of heritable disorders of connective tissue, Berlin, 1986. Am f Med Genef 1988;29:581-94.

Hollister DW, Godfrey M, Sakai LY, Pyreritz RE. Immunohistologic abnormalities of the microfibrillar-fiber system in the Marfan syndrome. N Engl F Med 1990;323:152-9.

Kainulainen K, Pulkkinen L, Savolainen A, Kaitila I, Peltonen L. Location on chromosome 15 of the gene defect causing Marfan's syndrome. N Engl f Med 1990;323:935-9.

5 Lee B, Godfrey M, Vitale E, Hori H, Mattei M-G, Sarfarazi M, et al. Linkage of Marfan's syndromo and a phenotypically related disorder to two different fibrillin genes. Nature 1991;352:330-4O

6 Dietz HC, Cutting GR, Pyreritz RE, Maslen CL, Sakai LY, Corson GM. Marfan's syndrome caused by a recurrent de novo missence mutation in the fibrillin gene. Nature 1991;352:337-9.

7 Kainulainen K, Steinmann B, Collins F, Dietz HC, Francomano CA, Child A, et al. Marfan'CW syndrome: no evidence for heterogeneity in different populations, and more precise mapping $o \omega$ the gene. Am F Hum Genet 1991;49:662-7.

8 Harper PS, Clarke A. Should we test children for "adult" genetic diseases? 1990;335:1205-6.

9 Harper PS. The case against (the human genome). Nature 1991;353:9.

90 Geva T, Hegesh J, Frand M. The clinical course and echordiographic fearures of Mafa, syndrome in childhood. Am 7 Dis Child 1987;141:1179-82.

11 McKusick VA. Abraham Lincoln and Marfan's syndrome. Nature 1991;352:280.

\title{
Doctors in the making
}

\section{How to resolve problems in the preregistration year}

The publication of Doctors in the Making is an important contribution to what is becoming an impressive body of published work on the problems of junior doctors. Having conducted a series of structured interviews with house officers, consultants, nurses, and managers, the authors present their results and base a comprehensive list of recommendations on them.

The interviews confirm previous research. House officers become disillusioned, ${ }^{2}$ are stressed and unsupported, ${ }^{3}$ and receive little formal training. ${ }^{+}$They feel undervalued by the hospital, and their perception is correct. Managers and consultants avoid or deny the implications of this and the punitive conditions in which house officers work. ${ }^{5} \mathrm{~A}$ worrying finding from this report is that consultants seem to be largely ignorant of the recommendations of the General Medical Council on the training and supervision of house officers. ${ }^{6}$

Possibly the most refreshing aspect of Doctors in the Making is that it appreciates there is a complex relationship within the organisation that is dynamic and involves several professional groups. It then uses this relationship to formulate a series of linked, multidimensional proposals aimed at the resolution of house officers' problems. The past is littered with well intentioned initiatives aimed at one component rather than at the problems as a whole. Hours of work, education, and support are all important topics, but the key to improving the lot of house officers lies in enhancing their job satisfaction by a combination of diminishing their workload, improving the appropriateness of their work and how much control they have over it, recognising their contribution and giving them feedback on their performance, enabling their active participation in the management of their work, and giving them an educational experience that they will perceive as valuable.

None of this need be complex or expensive or require centralised direction. A striking feature is how the percep tions of house officers changed in response to simple interven $\mathbb{D}$ tions, such as consultants appearing interested in their lif outside work.

The report contains a new analysis of the role of house officers. Instead of the traditional model, which makes al? aspects of a preregistration house officer's work the respon sibility of consultants, different lines of accountability are suggested for different parts of the work. For some part house officers would be accountable to nurses anक्ष managers - a long overdue acknowledgment of a reality tha? should be taken on board by doctors, rather than responded to defensively.

The important and informal contribution made to the education of house officers by senior nursing staff is recog $\frac{D}{0}$ nised, and the report suggests that it should be formalised The authors acknowledge that in doing this there could be difficulties in definitions and responsibilities. Given thes undoubted overlap in care between house officers and nurses it is surprising that the concept of partnership in the provisiof of care, at least at ward level, is avoided. If there is a genuinळ mutuality between the nursing and medical professions it must be logical to integrate them rather than preserve the traditional model. The relationship between house officer an $\$$ ward sister must be a sensible place to start.

The main difficulty with a multidimensional approach wi be how to drive it. Professional defences can be overcome, and finding financial and human resources is often an overrate problem. Essentially the authors advocate changing the culture according to the tenets of good personnel manage? ment. National bodies, such as the General Medical Council and the Junior Doctors' Committee, have a part to play, mainly in enabling change. The real power and possibilities, 
however, lie with the contracting process. Will purchasers preferentially buy services from providers with an explicit commitment to managing human resources effectively, even if this entails a price in terms of volume for the increase in quality? Will providers budget for the undoubted costs of education?

The problems of junior house officers are well known and have been largely ignored as they worsen. Doctors in the Making gives a comprehensive analysis of these problems and offers a welcome means for their resolution. The medical and nursing professions and the NHS management should have the will to implement the solutions at ward level, acknowledging that a complete solution has to address what is a complicated, multifaceted, and linked series of problems.

Consultant in Psychological Medicine,

STEPHEN HUNTER

St Cadoc's Hospital,

Caerleon,

Gwent NP6 1XQ

1 Dowling S, Barrett S. Doctors in the making. The experience of the pre-registration year. Bristol: SAUS Publications, Bristol University, 1991

Allen I. Doctors and their careers. London: Policy Studies Institute, 1988

3 Dudley HAF. Stress in junior doctors. I. Stress and support. BMF 1990;301:75-6.

Biggs J. The pre-registration year 1983-1988. Med Educ 1989;23:526-33.

5 Light D. Towards a new sociology of medical education. F Health Soc Behav 1989;29:307-21

6 General Medical Council. Recommendations on general clinical training. London: General Medical Council, 1987.

\section{Training in obstetrics}

\section{"What's wrong with the specialty of obstetrics and gynaecology?"}

This was the question asked of about 180 registrars and senior registrars by the vice president of the Royal College of Obstetricians and Gynaecologists at the start of a lively meeting on recruitment and training held by the college last month. Obstetrics and gynaecology is a fascinating, innovative, and progressive branch of medicine encompassing two acute specialties and combining medicine and surgery with the excitement of midwifery. Yet there is clearly something wrong because recruitment to and retention in the specialty have deteriorated. Over the past five years the number of United Kingdom graduates obtaining membership of the college has not increased to match the small increase in consultant numbers; the number of United Kingdom career senior house officers has fallen steadily to critically low levels; and there is an alarming wastage of trainees after membership, with a third leaving the discipline within five years of obtaining membership ( $53 \%$ of women, $27 \%$ of men).

The three main problems highlighted at the meeting were too little career guidance, a perceived lack of either a curriculum or a structure to the training, and the long hours worked. The lack of career guidance stems from a lack of definition of the aims and objectives of training for either career or vocational trainees. ${ }^{1}$ Training is defined almost entirely in terms of time rather than experience, so that juniors tend to be overexperienced but undertrained. Training goals should include not just knowledge and technical skills but skills in management, communication, teaching, and so forth that are essential for today's consultant.

Six hundred and forty six trainees had returned a preliminary postal questionnaire on hours of work and training (response rate of $37 \%$ for senior house officers, $57 \%$ for registrars, and $68 \%$ for senior registrars). A clear majority favoured a maximum of a 1 in 4 rota. Shift systems were favoured by senior house officers but were rejected by the majority of registrars, while cross cover was wholly rejected because it would be detrimental to patient care. Just under half of the respondents had seriously thought about leaving obstetrics and two thirds of these gave the effect of hours of work on themselves and their families as the main reason.

Other problems identified were the length of training, the lack of part time posts, the often appalling standard of on call accommodation, and the perceived necessity for a second degree. Contrary to what some believe, medicolegal problems were not an important deterrent. Some of the problems experienced by vocational trainees are similar. ${ }^{1}$ There are, however, important differences, and the royal college is currently reviewing vocational training for general practice. The solutions to these problems are obviously vitally important for the future of the specialty. Some solutions are already being worked on: the college is already looking at structured training programmes; the membership and the diploma examinations are under review; the aims and objectives of training up until membership will be clearly defined; and regular formal and informal assessments will almost certainly replace parts of the current examination. The role of the district tutor needs to be promoted. Training needs to be flexible to accommodate part time training where necessary; the college now has an adviser in part time training. Part time consultant posts have been advocated before, and this need was reiterated at the meeting. ${ }^{2}$

Any solution to the hours of work issue requires more manpower at all levels. Indeed, the meeting highlighted once again the current acute shortage of consultant obstetricians. Consultants in the United Kingdom have more responsibility for more deliveries per year than those in any other country in Europe; they should have designated labour ward sessions to supervise trainees, but this happens in only a quarter of British hospitals. ${ }^{3-6}$ Only increased consultant numbers can shorten the time spent training and allow it to be given a higher priority. The importance of training must be acknowledged by the government and the Department of Health. If there is no increase in consultant numbers then the effect of shorter working hours for juniors and an increased commitment to training will be to exacerbate the already acute shortage of consultants. This will drive even more of our keen dedicated trainees out of the discipline. In the end it will be the women of Britain who will suffer. Once again the royal college has sounded a note of warning to the government that the standard of care of pregnant women is not as it should be.

SUSAN M BLUNT

Consultant Obstetrician and Gynaecologist,

Solihull Hospital,

Solihull,

West Midlands B91 2JL

1 Smith LFP. GP trainees' views on hospital obstetric vocational training. BMF 1991;303:1447-50. 2 Royal College of Obstetricians and Gynaecologists. Memorandum of Council on the role of women doctors in obstetrics and gvnaecology. London: RCOG, 1987.

Report on Confidential Enquiries into Maternal Deaths in the United Kingdom 1985-87. London: HMSO, 1991

4 Ennis M, Vincent CA. Obstetric accidents: a review of 64 cases. $B M \mathcal{F} 1990 ; 300: 1365-7$

5 Ennis M. Training and supervision of obstetric senior house officers. $B M 7$ 1991;303:1442-3.

6 Royal College of Obstetricians and Gynaecologists. Report to the Health Committee of the House of Royal College of Obstetricians and Gynaecologists. Report to the
Commons on intrapartum care. London: RCOG, 1991. (1 May.) 